\title{
Liturgical and spatial aspects of the consecrative inscriptions of Roman churches, $11^{\text {th }}-13^{\text {th }}$ centuries
}

The dedication of a church building was an event of special significance under the aegis of the high medieval Reform movement in the Western church. Its symbolism reflected the ecclesiological ambitions of the Gregorian Reform ideology, and the dedication rite itself was a demonstration of the sacred power of the bishops. ${ }^{1}$ At the same time the liturgy was an appealing and moving experience for all participants. In Louis I. Hamilton's words, the dedication ceremony "exerted a kind of charisma", which needed to be maintained in the collective memory of the community connected to the consecrated building. ${ }^{2}$ The annual celebration of the Feast of the Dedication and the installation of epigraphs were the proper tools to foster this memory.

The popes of this period certainly acted as model bishops by taking their duty to consecrate churches particularly seriously. As the pinnacle of an increasingly firm ecclesiastical hierarchy, the pope was aware of the political and ecclesiological potential of dedicating important churches. Popes Urban II (1088-1099) and Innocent II (1130-1143) consecrated the high altar and the building respectively of the abbey church at Cluny, the largest and one of the grandest edifices of medieval Christendom, and at the same time a major centre of church Reform. ${ }^{3}$ This was therefore not only a period of intense church building in Western Europe, but also a period of strong papal commitment to the spiritually and politically significant act of church dedication. ${ }^{4}$

The situation in the papal city of Rome was slightly different to that of many other urban and monastic centres in Europe. ${ }^{5}$ There was no need to build large-scale churches since the majestic basilicas of the Early Christian era were still fulfilling their functions, and were the embodiment of a significant part of Rome's Christian identity. Nevertheless, there was considerable activity related to church building in Rome in these centuries: many Early Christian basilicas were restored and provided with new altars, and a number of remarkable new churches were erected. Some of these were replacements for Early Christian predecessors; others were new foundations for example at the behest of the new religious orders. In point of fact, the lion's share of the newly built churches were modest structures that made the existing ecclesiastical network dominating the late antique and medieval city denser. They were chiefly situated in the abitato of the Tiber bend. ${ }^{6}$

A recent study by Anna Holst Blennow of consecrative inscriptions in high medieval Rome has made the material contained in these texts easily accessible. ${ }^{7}$ Holst Blennow has

\footnotetext{
${ }^{1}$ L. I. HAMILTON, A Sacred City. Consecrating Churches and Reforming Society in Eleventh-Century Italy (2009).

${ }^{2}$ HAMILTON, Sacred City esp. p. 77 seq.

${ }^{3}$ Bibliotheca Cluniacensis, in qua SS. Patrum Abb. Clun. Vitæ, miracula, scripta, statuta, privilegia chronologiaque duplex, item Catalogus Abbatiarum, prioratuū, Decanatuum, cellarum, et Eccles. à Clun. Cœnobio dependentium, unà cum Chartis, et Diplomat. donationum earumdem, ommia nunc primum ex MS. Codd. collegerunt Domnus Martinus MARRIER \& Andreas QUERCETANUS, qui eadem disposuit, ac not. ill. M. MARRIER / A. Du CHESNE eds. (1915 / orig. 1614), p. 518, 1639-1640.

${ }^{4}$ HAMILTON, Sacred City p. 23-25.

${ }^{5}$ A concise overview in R. FAVREAU, Inscriptions de dédicace d'églises et de consécration d'autels à Rome, XleXIIle siècles, in: Arte d'Occidente: temi e metodi. Studi in onore di Angiola Maria Romanini, A. CADEI / M. RIGHETTI TOSTI-CROCE et al. eds. (1999), p. 947-956.

${ }^{6}$ Cf. G.M. AnNoscIA, Scritture esposte di committenza pontificia (XII secolo) in tre chiese dei rioni VI e VIII di Roma, in: Temporis signa 5 (2010), p. 133-147.

${ }^{7}$ A. HOLST BLENNOW, The Latin consecrative inscriptions in prose of churches and altars in Rome 1046 - 1263 :
} 
edited and studied 43 inscriptions in prose, dated between 1046 and 1263, that hold a wealth of information concerning church history, architecture, liturgy, hagiography, piety etc. ${ }^{8}$ These commemorative inscriptions are the most important source of information regarding the execution of the ritual of dedication and its significance, since literary descriptions of church consecrations from Rome, at that time, are absent. However one account provided in the chronicle of Montecassino regarding the solemn dedication of the new abbey church by pope Alexander II, in the presence of numerous cardinals and bishops in 1071, must demonstrate many 'Roman' features and may be used as comparative material. ${ }^{9}$ The epigraphs are important objects in their own right, not only because of their shape and lettering, but also because of the spatial disposition and the visual effect of the inscriptions in the architectural space..$^{10}$

In this contribution I will - benefitting from Holst Blennow's valuable publication address some specific aspects of Roman churches in the High Middle Ages gleaned from the evidence in the consecrative inscriptions. The texts and their physical supports will be examined, specifically the features that provide information on the mise-en-scène of worship in the Roman churches of this period. The selected evidence will be discussed in two sections: the first focussing on the spatial disposition of the inscriptions themselves, the second on the liturgical disposition they are referring to, particularly in relation to the cult of relics. For convenience sake, references will be made to Holst Blennows catalogue with the abbreviation $\mathrm{HB}+$ catalogue number. ${ }^{11}$

\section{General remarks}

Some preliminary remarks may be permitted preceding the announced sections. First of all, there are many common features in the formal scheme and in the formulas used in the inscriptions. ${ }^{12}$ The constituents of the scheme are, usually, a protocol with the date, a main text with the dedication formula and a catalogue of relics. Sometimes an eschatocol (closing section) exists. The prevalence of this scheme makes the exceptions all the more intriguing. As far as the physical appearance of the preserved inscriptions is concerned, more diversity can be discerned. There are striking differences in style and quality of the script and the dimensions and shape of the slabs differ considerably.

The inscriptions are typically meant to be read in loco: expressions like haec ecclesia and hoc altare refer to the place where the beholder is standing. Some inscriptions of church

\footnotetext{
edition with translations and a commentary on language and palaeography (2011). Blennow does not make use of the fundamental article of FAVREAU, Inscriptions.

${ }^{8}$ Nine inscriptions of dubious date are discussed in an appendix to the catalogue.

${ }^{9}$ Chronica monasterii Casinensis. Die Chronik von Montecassino. H. HoffMANN ed. (MGH SS 34, 1980) 3.29-30 p. 398-402.

${ }^{10}$ In an important volume on the medieval consecration rite two contributions deal with inscriptions: C. TREFFORT, Une consecration 'à la lettre': Place, rôle et autorité des textes insctis dans la sacrlaisation de l'église, in: Mises en scène et mémoires de la consécration de l'église dans l'occident médiéval. D. MeHu ed. (2007), p. 219-251; Y. CODOU, La consécration du lieu de culte et ses traductions graphiques: Inscriptions et marques lapidaires dans la Provence des Xle -XIle siècles, in: ibidem, p. 253-282.

${ }^{11}$ I refrain from quoting the texts and refer to the careful edition of the inscriptions in Holst Blennow's book. I will limit myself to the inscriptions in her catalogue and will not adduce other material like inscriptions in verse and inscriptions consisting of pure relic catalogues. My impression is that they will not change the picture essentially.

${ }^{12}$ A detailed analysis in Holst BLENNOW, Inscriptions p. 239-282; cf. ANNOSCIA, Scritture p. 141-144.
} 
consecrations even abstain from mentioning the name of the church (HB 22 / 28). No mention whatsoever is made of the administrative or historical status of the church in question. Characteristics of formula, shape, and execution lack any sign of systematic differentiation between titular churches, deaconries, votive or monastic churches. To take only one case in point: SS. Michele and Magno in the Borgo was well known to be one of the famous scholae for foreign nations in Early Medieval Rome, in this case the Frisians. Yet the inscription of the dedication of a new church by Innocent II in 1141 does not make any reference, not even implicitly, to the historical identity of the church (HB 22). The only 'local' information is the name of the archpriest, Stephen, thanks to whose "studium et industria" the rebuilding had been realized. Stephanus is not quite a typical Frisian name, and maybe at the time of the rebuilding of the church had no function any more for these distant people from the shores of the North Sea. Nevertheless, the tradition was still alive, witness the later monumental inscription, still preserved in the church, which celebrates the heroic role of the Frisians fighting against the Saracens in the ninth century. ${ }^{13}$ The usual dating of this slab in the later $13^{\text {th }}$ century needs the critical assessment of experts, but it is clear that we are dealing with an interesting testimony of memory-and-identity made by a nation that had reason to cultivate a past that had become invisible in the epigraph of 1141.

Another observation concerns the division of liturgical roles. The inscriptions confirm the central responsibility of the bishop of Rome in the dedication ceremony. In by far the majority of the documented cases, the pope himself acts as the principal consecrator of a church and its high altar ${ }^{14}$. In cases of consecrations when the church has more than one altar, the dedication of secondary altars is delegated to other bishops, frequently to the suburbicarian cardinal-bishops. In Montecassino, pope Alexander II consecrated the high altar of St. Benedict and the central apse altar of St. John, while three other altars were consecrated by bishops. ${ }^{15}$ Nevertheless there are inscriptions which bear evidence of occasions in which the consecration of one secondary altar in an existing church was performed by the pontiff himself. Of the series of seven secondary altars in S. Cecilia, one was dedicated by Gregory VII (1073-1085), the others by cardinal bishops (HB 4). ${ }^{16}$ Pope Alexander III (1159-1181), just after his return to Rome in 1179, following a long struggle with the emperor and antipopes, condescended to dedicate a side altar in a minor church with his own hands. This altar of the Virgin in S. Maria in Aquiro is defined "altare minor" in the inscription (HB 24). In sum: notwithstanding his daily involvement in 'world politics' and his repeated - often forced - absences from the city, the pope generally took his role as the local bishop of Rome remarkably seriously. Independent altar consecrations were in principle also performed by the pope, but he was frequently represented by one of the cardinal bishops even for the dedication of high altars (e.g. HB 6 / 9 / 10).

A minor number of inscriptions make mention of the patron, commissioner or donor of the construction or renewal of the church or altar. ${ }^{17}$ Sometimes, this was the cardinal priest or cardinal deacon of the titular church. Since he was not a bishop, he was not authorized to function as consecrator and may have felt the need to emphasize his special role. Examples are the inscription commemorating the dedication of a side altar of St. Nicolas in the church of SS. Giovanni e Paolo in 1157 (HB 23) and that of the church

\footnotetext{
${ }^{13}$ M. MusKens, Santi Michele e Magno dei Frisoni (1993), p. 98-109.

${ }^{14}$ FAVREAU, Inscriptions p. 948: in 55 known inscriptions the pope is the consecrator 24 times.

${ }^{15}$ Chronica Cassinensis 3. 29, p. 400.

16 P.C. CLAUSSEN, Die Kirchen der Stadt Rom im Mittelalter 1050-1300 (2002) 1, p. 227 seq.

${ }^{17}$ Cf. HOLST BLENNOW, Inscriptions p. 273-275.
} 
dedication of S. Adriano in 1228 (HB 32). The cardinal priest John of Sutri of SS. Giovanni e Paolo, also responsible for a restoration of the early Christian basilica, is said to have constructed "such a complete work together with the altar". ${ }^{18}$ In the case of churches lacking the titular status, the first priest serving the church is occasionally mentioned in the inscription, like Petrus of S. Tommaso ai Cenci (HB 10) and Stephanus in the above mentioned inscription in SS. Michele e Magno (HB 22). The consecration of the minor church of S. Lorenzo de Nicolanaso in 1241 was organized by its priest Peregrinus, who enjoyed the "help" (adiutorium) - no doubt financially - of Matthew and his wife "the countess" (HB 35). The same allocation of roles appears at the church dedication of S. Eustachio in 1196 with the archpriest Peter (HB 28). The absence of donor names in most inscriptions would seem to imply that patronage by the officiating head of clergy, responsible for the church, was usual.

In some instances, extremely ambitious commissioners or donors stand out. In S. Crisogono, the usual model of the inscriptions is even broken to highlight the role of cardinal priest John of Crema on the occasion of the dedication of his oratory in 1123 (HB 16). The inscription enlarges upon the donations made by Cardinal John in favour of his title church. Furthermore the group of influential cardinals present in the ceremony is out of the ordinary for such a minor sanctuary. In the same year, the papal chamberlain Alfanus takes pains to emphasize his role as a donor to S. Maria in Cosmedin (HB 13). Also noteworthy is the exceptional private note from 1090 that is contained in the inscription of S. Maria in Cappella: a brief version of the usual scheme, but ending with "O Christ Saviour, give Damasus life after death" (HB 5).

Maybe surprisingly, there is little or no difference between the inscription models referring to the dedication of a church and the dedication of an altar. The scheme and the contents are basically the same. No inscription refers to the sophisticated ritual of church dedication apart from the deposition of the relics, which was precisely the feature in common with altar dedications. ${ }^{19}$ Actually, a church dedication always included at least one altar dedication and this was obviously the crucial message in the high medieval inscriptions. In only one case, is the altar dedication not explicitly mentioned. When two cardinal bishops are said to have consecrated S. Maria in Cappella in 1090 it is only noted that relics "are present" (HB 5). Only twenty-three years later, a new high altar with new relics was consecrated in this church, for which a new epigraph was made (HB 9). Two other exceptions are of interest. On the altar of S. Maria in Portico, a short inscription on the cornice refers to the consecration of the church ("hoc templum"), whereas the long - and much more visible - inscription on its front recalls the altar consecration (HB 2). The presence of the pope together with a retinue of numerous prelates suggests a church rather than an altar dedication. The inscription of S. Maria in Saxia in 1123 mentions only the dedication of the high altar, but also here, the context suggests the consecration of the church (HB 12).

\section{Text and place}

\footnotetext{
${ }^{18} \mathrm{Cf}$. MONDINI in: CLAUSSEN, Kirchen 3, p. 76 seq. (with inaccurate interpretation of a priest as consecrator of the „Hauptaltar“).

${ }^{19}$ For the Roman ritual in the twelfth century see M. ANDRIEU, Le pontifical romain au moyen-âge. 4 vols. (19381941) 1, p. 176-195.
} 
Regarding the location of consecrative inscriptions in the church interior, it is logical to make at least a theoretical distinction between texts referring to church consecrations and those commemorating altar consecrations. Of the known inscriptions, half relate to the altar, the other half to church consecrations. ${ }^{20}$ Usually, the texts address an audience that is able to see and understand at a glance to which object the text refers: haec ecclesia / hoc altare. Hence, there is an unequivocal visual relationship between text and place. The text makes reference to one specific place, either the specific object of an altar or the fabric of a church as a whole. However, hardly any inscription has been preserved in situ, meaning that indirect evidence is called for in order to achieve a picture of the visual effect of the original.

In the case of altar consecrations, the inscription must have been visible in close vicinity to the altar referred to. Yet, different categories may be distinguished according to contents, setting and visibility. ${ }^{21}$

Sometimes, the altar itself was inscribed in memory of its consecration. The front of the high altar of Old St. Peter's had the name of pope Calixtus II (1119-1124) on it. The chronicler Peter Mallius, who wrote a treatise on the Vatican basilica half a century after the consecration event, states that he found the information regarding the consecration of the renewed altar over Peter's tomb, undertaken by Calixtus in 1123, in the basilica's archives and from hearsay by his older colleagues in the Vatican chapter. ${ }^{22}$ Obviously an inscription with detailed information regarding the reconsecration was not in situ. The name of the consecrator on the altar itself and an entry in the liturgical books of the basilica may have been sufficient. The latter was necessary for the annual celebration of the feast of the dedication by Calixtus on March 25. ${ }^{23}$ According to Giacomo Grimaldi, who observed the medieval altar before its demolition in 1590, Calixtus' name was inscribed on the altar front facing towards the nave. ${ }^{24}$ Nothing is told, however, about its exact position and lettering. Probably, the inscription was hardly ever visible, because the marble altar was usually covered with metal plating and / or embroidered fabric. ${ }^{25}$ In short, this type of inscription may be seen as the minimal variant of a consecrative inscription.

A preserved example of a summary inscription on the altar itself refers likewise to Calixtus II. In his pontificate, a new high altar, made from an ancient bathtub, was installed in $\mathrm{S}$. Maria in Cosmedin. The inscription was written on the rim of the mensa slab over the tub (HB 13). It makes a concise statement regarding the consecration of "hoc altare" by Calixtus II and - highly atypical - of the gifts of the patron Alfanus. ${ }^{26} \mathrm{~A}$ consecrative inscription on or under the edge of the mensa became more frequent in the Early Modern period, but in the middle ages only few examples are known (HB 2). ${ }^{27}$ Once again, the inscription was probably not permanently visible due to the customary textiles covering the altar. In S. Maria in Cosmedin, however, it is clear that this inscription was never intended to instruct the

\footnotetext{
${ }^{20}$ FAVREAU, Inscriptions p. 947: 27 churches, 28 altars.

${ }^{21}$ Cfr. Holst BlenNow, Inscriptions p. 236 seq.

22 Descriptio Basilicae Vaticanae: R. VAlENTINI - G. ZUCCHETTI, Codice topografico della città di Roma $(1946) 3$, p. 375-442, esp. p. 435 seq.

${ }^{23}$ Liber Anniversariorum: S. DE BLAAUW, Cultus et decor. Liturgia e architettura nella Roma tardoantica e medievale: Basilica Salvatoris, Sanctae Mariae, Sancti Petri (1994), p. 647 seq.

${ }^{24}$ G. GRIMALDI, Descrizione della basilica antica di S. Pietro in Vaticano. R. Niggl ed. (1972), p. 204 seq.

${ }^{25}$ Cf. Montecassino: Chronik von Montecassino 3.32, p. 404.

${ }^{26}$ S. RICCIONI, Epigrafia, spazio liturgico e Riforma Gregoriana, un paradigma: Il programma di esposizione grafica di Santa Maria in Cosmedin a Roma, in: Hortus Artium medievalium 6 (2000), p. 143-156.

${ }^{27}$ E.g. on the new high altar in St. Peter's. 1590: GRIMALDI, Desciptio p. 205. Cf. J. BRAUN, Der christliche Altar in seiner geschichtlichen Entwicklung (1924), p. 302 seq.
} 
audience about the altar's dedication. That aim was performed by another, much more extensive epigraph that survives on the inner wall of the apse (fig. 1). It is a large slab, more than one meter in width and clearly executed by the same workshop (HB 14). It repeats the reference to the dedication of the altar ("hoc altare") by Calixtus, now specifying at length the relics placed in it. The existence of this second epigraph, close to the altar, but visible from a wider distance, confirms the differentiation between discreet inscriptions on the altar itself, which may be characterized as identifying labels, and texts intended for visual communication with a wider audience. Additionally, Alfanus found other ways to remind the visitor of his generosity as a donor. ${ }^{28}$

Not including those rare inscriptions on the altars themselves the wall slab in S. Maria in Cosmedin is one of the very few medieval Roman church consecrative slabs preserved in its original position. Size and script are unmistakably aimed at visual display. From the chancel enclosure in front of the presbytery, the altar and the epigraphy are seen in one glance.

This extensive type of text could also have been applied to the altar itself. However, the preserved examples are limited to a very specific group of ancient cippi that were reused as Christian altars in the high middle ages. For that reason, a cavity for the deposition of relics was hollowed out in the top of the block-shaped marble. The original 'pagan' inscriptions were erased and new texts carved in the panels destined for them. The most interesting example is the marble block now in S. Galla (HB 2). One inscription on the top cornice actually refers in brief terms to the consecration of the church of $\mathrm{S}$. Maria in Portico by Gregory VII in 1073. The other text is in the writing fields at the front and right side of the block, and mentions the consecration of the altar and the relic deposition therein more extensively. Stefano Riccioni has argued that not only the ancient vegetal and animal motives in the decorated border, but also the script of the epigraphy were well-considered expressions of the Reform spirit under Gregory VII, the consecrator of the altar. The classical style of the lettering can be compared with the so-called Bibbie Atlantiche of this period. ${ }^{29}$

The inscriptions on the sides of this particular type of altar were obviously meant to be visually effective, which must have been inspired by the continuity of the ancient cippus as a bearer of texts. Most probably, the fashion of reuse of cippi or pagan funerary altars as church altars was short-lived, at least in the case of high altars (HB 8), and limited to the decades marked by the two preserved examples (1073-1113) (fig. 2). The conspicuous inscriptions on the reused cippi were certainly also a means of their Christianization, ${ }^{30}$ likewise perhaps the inscription above the ancient bathtub in S. Maria in Cosmedin.

The usual type of altar in medieval Rome was a massive block of masonry clad with marble, slightly articulated by pilasters at its corners. ${ }^{31}$ Almost all the preserved inscriptions referring to altar dedications are on independent marble slabs. This leaves two possibilities for their original placing: as part of the altar itself or mounted on a wall, screen or platform front close to the altar in question. The size of the remaining slabs is sometimes remarkably close to the standard dimensions of high medieval altar blocks. This is true, for instance, for the slab in S. Cecilia with the memorial text of the dedication by Gregory VII in $1080 .{ }^{32}$ The

\footnotetext{
${ }^{28}$ RICCIONI, Epigrafia p. 146, 147, 148 (inscriptions on the cathedra, pergola and tomb monument in the narthex).

${ }^{29}$ RICCIONI, Gli altari di S. Galla e S. Pantaleo: Una 'lettura' in chiave riformata dell'antico, in: Hortus Artium Medievalium 11 (2005), p. 189-200.

${ }^{30}$ Cf. HOLST BlenNOW, Inscriptions p. 48 seq.

${ }^{31}$ CLAUSSEN, Kirchen 1, p. 247 seq.

${ }^{32}$ Cf. Claussen, Kirchen 1, p. 228 no. 8.
} 
inscription occupies only the upper part of the $96 \times 1.32(\mathrm{H} \times \mathrm{W})$ large piece of marble. In highly classical lettering the inscription gives just the date and the papal consecrator of "hoc altare" (HB 4). The slab may plausibly have been the front of the altar and its inscription a slightly longer version of the minimal type on Old St. Peter's high altar. From S. Nicola dei Funari comes a slab with the unusual measurements of $34 \times 1.60(\mathrm{H} \times \mathrm{W})(\mathrm{HB} 25)$. It commemorates the consecration of the high altar and the deposition of relics by the bishop of Orte in 1180 and ends with a threat of excommunication to those who sell or pawn the utensils and goods of the church, also unusual for this genre. ${ }^{33}$ It was clearly meant to be permanently visible for the visitors and may have been part of the altar front.

However, caution is called for. Apart from the few exceptions already mentioned none of the preserved medieval altars in Roman churches bear an original inscription. It is true that altars were rewarding objects of renewal, victims of changing styles and fashions, so the majority of medieval ensembles have been dismantled long since. As Joseph Braun established in 1924, medieval altar blocks and altar mensae bearing inscriptions commemorating the consecration and / or the relics are extremely rare in Latin Europe. ${ }^{34}$ Yet, examples exist of consecrative texts inscribed on the mensa or the altar stipes from different periods in different countries, generating a theoretical possibility for a somewhat wider spread of this phenomenon.

The apse epigraph of S. Maria in Cosmedin may reflect the usual device in Roman churches: the attachment of a marble slab with the inscription on a wall, slightly above eye level and close to the altar in question, clearly visible to those viewing the altar. Sometimes, the mere dimensions of the slab dictate that this is the only imaginable solution. The altar of the Holy Angels in S. Sabina has a consecrative inscription on a marble of $140 \times 50 \mathrm{~cm}(\mathrm{H} \mathrm{x}$ W) (HB 38), the position of which is conceivable only on a wall or wall pillar of the side apse where the altar was located. Other examples of altar inscriptions on walls are at least documented, such as the crypt of S. Sebastiano with an altar dedication ("hoc altare") in 1218 (HB 31). In S. Adriano, the ancient Curia Senatus, the extensive inscription describing the relics in and under the high altar and the consecration of the church in 1228 by Gregory IX was still to be seen in the late $16^{\text {th }}$ century near the high altar in the apse (HB 32). When more than one altar consecration is referred to in one inscription, it is not plausible that the epigraph was mounted on one of those altars. For example, the consecration of three side altars in S. Agnese f.I.m. in 1256 is commemorated in one large epigraph, which must have been located at a 'neutral' spot in the church interior from which all three altars were visible (HB 40). These Roman examples correspond to general practice in the Latin church. The visible documentation of the names and / or consecration data of altars has from time to time been encouraged unequivocally by church authorities. ${ }^{35}$ Notwithstanding the fact that relatively few examples have been preserved, enough remains exist to surmise that carved or painted consecrative inscriptions on a wall in the direct vicinity of the altar and in visual unity with it must have been a widespread tradition.

\footnotetext{
${ }^{33}$ Derived from papal privileges and letters: Holst BLENNOW, Inscriptions p. 240, p. 275 seq.

${ }^{34}$ BRAUN, Altar 1, p. 363-366, 720 seq.

35 Braun, Altar 1, p. 722-724; e.g. the decree of William de Blois, bishop of Worcester in 1229 (ibidem p. 724):

"In ecclesiis dedicatis annus et dies dedicationis et nomen dedicantis et nomen sancti in cuius honore dedicate est ecclesia distincte et aperte scribantur circa majus altare in loco ad hunc [finem] idoneo; idem fiat circa minora altaria".
} 
The inscriptions referring to the consecration of the church as a whole might be supposed to be less bound to one specific location within the church. Nonetheless, the altar or altars are always substantial elements in the texts, so that a location in a field of vision with these altars is the most logical (HB 32). Some inscriptions make this clear in their wording: Calixtus II dedicated S. Agnese in Agone in 1123: "haec ecclesia", and he deposited the relics "in hoc altari" (HB 11). This only makes sense if the epigraph was located in the vicinity of the high altar. On the other hand, the church dedication inscription of S. Lorenzo in Lucina from 1130 mentions "haec ecclesia" but specifies the altar were the relics were placed as "in maiori altari" (HB 19). This distinction may suggest a greater distance from the altar. When the church was dedicated with the consecration of more than one altar, the epigraph referring to the event must have been installed at a central spot, spatially appropriate to all altars mentioned (e.g. HB $22 / 27$ / 28). ${ }^{36}$ The location of the inscription of S. Eusebio in the $16^{\text {th }}$ century "on the wall near the high altar" may be the original one of $1238,{ }^{37}$ since it falls within the field of vision containing the central altar and both flanking side altars in the transept (HB 33).

Numerous epigraphs have been relocated more than once due to remodelling and renovation of the churches. From the sixteenth century onwards, many slabs could be found in the entrance area of churches. If a narthex or portico existed, this seems to have become the ideal place to collect inscriptions and other membra disiecta in a kind of lapidary that confronted the visitor with the history of the church (e.g. HB $7 / 16$ / 33). There is no indication that the entrance hall had been the original location for consecrative inscriptions in the middle ages.

The proportions of some slabs suggest particular architectural locations where they were intended to be mounted. The long and narrow slabs may have been made for wall pillars, for example the just mentioned stone in S. Lorenzo in Lucina of $136 \times 43 \mathrm{~cm}(\mathrm{H} \times \mathrm{W})$ (HB 29) and that of S. Salvatore delle Coppelle $(128 \times 60 \mathrm{~cm})(\mathrm{HB} 27) .{ }^{38}$ Another slab in S. Lorenzo in Lucina, however, which commemorates the re-consecration of this church in 1196, has dimensions ( $101 \times 144 \mathrm{~cm} \mathrm{H} \times \mathrm{W})$ that leave its fixation on an altar front a possibility (HB 29). After mentioning the church dedication, this text concentrates exclusively on the relics put in the high altar. The supposition that the marble was a part of the altar block is supported by the fact, that the writing field is concentrated in the upper part of the slab leaving the lower third blank (fig. 3). This is not a plausible layout for a slab mounted high on a wall. ${ }^{39}$

It is debatable whether every consecration of a church or an altar in medieval Rome was documented by a stone inscription. A written account on parchment may have been the elementary 'proof' of the event. ${ }^{40}$ In the late $13^{\text {th }}$ century version of the Roman Pontifical it

\footnotetext{
${ }^{36}$ For S. Eustachio (HB 28), a relatively remote location of the epigraphy is documented in the 16th century: Decreta... Clementis pp.Octavi facta in visitatione ecclesiarum Urbis viii junii MDLXXXXII, Archivio Segreto Vaticano, Misc. Arm. VII 3, f. 64v: "[Ad Altare S. Luciae] Renoventur litterae, quae fidem faciant altare maius a fel. rec. Caelestino Papa IIII [sic] fuisse consecratum"; cf. HoLST BLENNOW, Inscriptions p. 127 seq.

${ }^{37}$ P. UGonIO, Historia delle stationi di Roma, che si celebrano la quadragesima (1588), p. 259v: "una tavola antica di marmo posta appresso l'altar grande". The high altar stood directly in front of the central apse in the transept; CLAUSSEN, Kirchen 1 p. 449 seq.

${ }^{38}$ ANNOSCIA, Scritture.

${ }^{39}$ Cf. e.g. HB 40 (S. Agnese), which was almost certainly not on an altar itself (see below), notwithstanding its measurements $(90 \times 128 \mathrm{~cm} \mathrm{H} \times \mathrm{W})$ : the inscription fills the entire surface.

${ }^{40}$ H. RöCKELEIN, Schätze in Altären. Profane Gebrauchsgegenstände im sakralen Raum, in: Le trésor au Moyen Age. Discours, pratiques et objets. L. BURKART et al. eds. (2010), p. 179-197 esp. p. 195 seq.
} 
was prescribed that such a document was to be placed with the relics in the altar, and probably a copy was also to be kept in the church archives. ${ }^{41}$ Epigraphy was an additional medium, but one with a strong communicative value. Visible inscriptions stimulated the visitors at least in the celebration of the anniversary of the dedication and the devotion and admiration for the treasure of relics housed in the church and many of them also reminded the faithful of the indulgences to be earned. ${ }^{42}$

\section{Liturgical appointments and the cult of relics}

The inscriptions contain interesting information about the hierarchy of altars within one church. From the $5^{\text {th }}$ century, the multiplication of altars had been possible only by considering these altars as the core of a more or less autonomous entity, an oratorium or a chapel. ${ }^{43}$ In practice, and in terms of spatial experience, many of these chapel altars could be perceived as secondary altars in one church with one high altar. This notion changed gradually in the early middle ages, when secondary altars became common features of unified church interiors. The shift is reflected in the high medieval inscriptions. There is one high altar, and there are several other altars in the same building, which can now be qualified as side altars. The well documented example of $\mathrm{S}$. Cecilia in the late $11^{\text {th }}$ century, counts five new altars in the church itself apart from the existing high altar, and two altars in adjoining rooms (the baptistery and Cecilia's bathhouse)..$^{44}$

In the case of newly built churches, a complete 'set' of altars may plausibly have been provided in one building programme. S. Tommaso in Parione (1139) has obviously only one altar (HB 21); SS. Michele e Magno (1141) has a high altar and an altar of the Virgin (HB 22); S. Eustachio (1196), S. Eusebio (1238) and S. Tommaso ai Cenci (1240) have three altars (HB 28 / 33 / 34). More important churches had a greater numbers of altars. In S. Agnese, three were added to the already existing altars in 1256 (HB 40).

For the splendid Early Christian basilica of S. Sabina, various inscriptions document the rearrangement of the interior following the handing over of the church to the Dominicans in 1222. A sixteenth century inscription is obviously based on an older epigraph, recalling the consecration of five altars in the lay part of the church, attached to the new dividing wall in front of the monks' choir. ${ }^{45}$ Pope Gregory IX consecrated the central altar, four cardinals took care of four side altars, either in 1229 or 1238 . The epigraph was visible close to or on the dividing wall. ${ }^{46}$ The small apses at the end of the aisles were provided with side altars in 1248 and 1263 respectively. Both had a typical Dominican identity: that of the Holy Angels (1248) reflecting the angelic cult in Dominic's order and that of Peter of Verona (1263) the recent martyr (died 1252) of the order. Both altars had a sizable consecrative inscription slab with large early gothic lettering (HB 38 / 43).

\footnotetext{
${ }^{41}$ Pontificale Guillielmi Durandi 2. 2. 4: ANDRIEU, Pontifical 3 (1940), p. 456.

42 Indulgences: HOLST BLENNOW, Inscriptions p. 268-273.

${ }^{43}$ De BlaAuw. Cultus et decor p. 485-487.

${ }^{44}$ Holst BlenNow, Inscriptions p. 29 seq.; CLAUSSEN, Kirchen 1, p. 227-229, 249-251.

${ }^{45}$ HOLST BleNNOW, Inscriptions p. 221-224.

${ }^{46}$ UGONIO, Stationi p. 10v: "Di questa consacratione ne è scolpita la memoria in una tavola di marmo, che era gia quivi appresso affissa".
} 
Almost all long variants of consecrative inscriptions include references to the deposition of relics, a crucial part of the dedication ceremony. ${ }^{47}$ In the Early Middle Ages, the dedication rite of churches in Rome was essentially a celebration of the Eucharist with a solemn deposition of relics. ${ }^{48}$ It was only gradually that additional rites like anointments were introduced into the Roman ritual, generally via Gaul. From the $8^{\text {th }}$ century, a procession with the selected relics from another church to the church to be dedicated also came into use. The catalogues included in the inscriptions confirm an obsession with relics that is typical for western medieval Christianity. Robert Favreau counts 260 saints and many further sanctuaria in the corpus of high medieval Roman inscriptions. ${ }^{49}$ Of course, the inscriptions provide no answer to the urgent question of where all the relics came from and what they looked like. Certainly, they were usually not packed in such luxurious shrines as the relic treasury of the papal palace chapel Sancta Sanctorum..$^{50}$ These relics in the Lateran palace chapel were, after all, destined for display and ritual use on certain exclusive occasions, whereas most other altar relics would never see the light of day after their deposition.

The major part of the inscriptions refers to the simplest disposition of the relics: in the altar sepulchrum, a cavity in or under the mensa or in one of the sides of the altar. The former funerary altar blocks from S. Maria in Portico and S. Pantaleo provide a good example of the standard relic sepulchrum in the shape of a hollow space in the top side of the block, which was closed after the deposition with a solid cover (fig. 4). ${ }^{51}$ We may presume that, in the majority of cases without further specifications, the relics mentioned in the inscriptions were in fact arranged in this way. The description "in quo [altare] reconditae sunt reliquiae [etc.]" (HB 6 etc.) has to be visualised as the placing of boxes with relics into a cavity of the altar block. Rarely, the containers holding the relics are specified, particularly in the consecrative inscription of the altar of the Virgin in S. Adriano in 1248 (HB 37). The relics were deposited in the altar in glass vessels, one of which is distinguished as 'black', a marble shrine, a black reliquary in the shape of a house (casella) and a large glass lamp. The deposition of reliquaries in the relatively small cavity of an altar structure is actually the standard procedure which was envisaged in the editions of the Roman Pontificale of the $12^{\text {th }}$ and $13^{\text {th }}$ centuries (but in part derived from the older Roman-German Pontificale from the Rhineland).

A few points from the ritual according to the Pontificale deserve to be highlighted. At the doorway of the church, the pope or bishop announces solemnly, to clergy and people, to whom the church is dedicated and whose relics will rest there. ${ }^{52}$ Those responsible for the construction and the functioning of the church are reminded of their duty of dotation. It is easy to see the inscriptions as reflections of this rite. The Pontificale continues that the deposition itself is concealed from the view of the faithful by a curtain that is hung between the altar and the people for the duration of the rite. The relics are brought in a solemn procession from outside and stowed away in capsae (relic boxes). The bishop prepares the cavity in the altar block, called confessio or sepulchrum, anointing it with chrism. After the deposition of the relics in this cavity, the sepulchrum is closed with an anointed stone called

\footnotetext{
47 Pontificale Guillielmi Durandi 2. 2. 94-97 and 2. 3. 21-42: ANDRIEU p. 475 seq., 482-487.

${ }^{48}$ S. DE BLAAUW, Die Kirchweihe im mittelalterlichen Rom: Ritual als Instrument der Sakralisierung eines Ortes, in: Sakralität zwischen Antike und Neuzeit, B. HAMm/ K. HERBERS/ H. STEIN-KeCKS eds. (2007), p. 91-99.

${ }^{49}$ FAVREAU, Inscriptions p. 952 and 954.

${ }^{50}$ E. THUN $\varnothing$, Image and relic: Mediating the Sacred in Early Medieval Rome (2002), p. 17-117.

${ }^{51}$ D. MANACORDA, Volusio ritrovato. Le reliquie dei martiri nel sepolcro del sacerdos geni, in: Bollettino dei Musei comunali di Roma 25-27 (1978-1980), p. 60-82.

52 The basic ritual in Pontificale Romanum sec. XII 17. 46-54: ANDRIEU, Pontifical 1 (1938), p. 186-188.
} 
sigillum (seal), which is firmly fixed with blessed mortar. Meanwhile, the choir sings Corpora sanctorum in pace sepulta sunt et vivent nomina eorum in eternum (The bodies of the saints are buried in peace, and their names will live in eternity)..$^{53}$ Then the mensa is installed over the altar and is also blessed and anointed. The pontificalia stipulate that the confessio has, preferably, to be made in the upper part of the altar and to be lined with marble. ${ }^{54}$ But it can also be a cavity on the front or rear of the altar stipes. ${ }^{55}$

In Rome the actual depository for the relics could vary more than the liturgical protocols suggest. Various collections of relics are remarkably extensive and would require more space than the small cavities in the above mentioned altars. ${ }^{56}$ In S. Maria in Cosmedin, the bathtub serving as high altar offered itself as an ideal place to house the sizable number of relics, among which the heads and arms of several saints (HB 14). An opening up executed in 1675 , revealed seven glass vessels holding relics inside the tub. ${ }^{57}$ This is to my knowledge the earliest example of an ancient tub serving as the stipes of an altar. Later, numerous sarcophagi and tubs would be reused as such and thus offer themselves as large-scale relic sepulchra, clearly recalling the symbolical meaning of the altar as a tomb.

A more complicated configuration characterizes St. Peter's high altar. Essentially, the pre-existing holy place venerated as the tomb of the Apostle Peter made a significant difference. The confessio, a small chamber underneath the altar, was the closest place to venerate the invisible tomb. Moreover, an annular crypt allowed access to the rear part of the confessio. In addition, in the high altar block of Gregory the Great and Calixtus II a relic sepulchrum was hollowed out in the masonry. In the upper part of the altar a cavity of $1.83 \mathrm{x}$ $65 \times 34 \mathrm{~cm}(\mathrm{~W} \times \mathrm{L} \times \mathrm{H})$ was located that had a small rectangular fenestella opening at the apse side. ${ }^{58}$ In a marble shrine inside the cavity two silver boxes containing cloth relics with labels referring to Peter, Paul, Christ and Mary were found during the excavation campaign of the 1940's. The uncial script of the labels suggests that these relics have been kept here since the seventh century. They must therefore have been retained during the reconsecration of the altar by Calixtus II. According to Mallius ${ }^{59}$, the renewal of the altar in 1123 was motivated by damage to the age-old marble revetment. No surviving record makes mention of a relic deposition on this occasion.

St. Peter's disposition was therefore the result of a very specific historical and topographical configuration. Yet it was frequently imitated in other churches, entirely or in part, and in a certain sense 'artificially', considering the lack of a pre-existing martyr's tomb. The term confessio used in the pontificalia for a small cavity in the altar block, was nothing more than a symbolical reduction of the chamber above the martyr's grave called confessio already present in the $5^{\text {th }}$ century in the Roman basilicas of St. Peter's and St. Paul's. Many other Roman churches had a real confessio in imitation of St. Peter's, mostly recognizable by an opening or fenestella underneath the altar base. The inscriptions, with a few possible exceptions, seem to ignore this typical Roman feature.

\footnotetext{
53 Pontificale Guillielmi Durandi 2. 3. 34: ANDRIEU, Pontifical 3 (1940), p. 485.

${ }^{54}$ Pontificale Romanum sec. XIII 23. 3: ANDRIEU, Pontifical 2 (1940), p. 423.

55 Pontificale Guillielmi Durandi 2. 3. 38-39: ANDRIEU, Pontifical 3 (1940), p. 486.

${ }^{56}$ Pontificale Romanum sec. XIII 23. 3: ANDRIEU, Pontifical 2 (1940), p. 423 mentions a square opening of 1 palmo (about $22 \mathrm{~cm}$ ).

57 HOLST BLENNOW, Inscriptions p. 71.

58 De BlaAuW, Cultus et decor p. 543.

${ }^{59}$ Descriptio Basilicae Vaticanae: R. VALENTINI - G. ZUCCHETTI, Codice topografico della città di Roma $(1946) 3, p$. 375-442, esp. p. 435 seq.
} 
The use of the term corpus for relics in several inscriptions cannot be disposed of as pure rhetoric, even if in some cases it may simply be so (HB 12)..$^{60}$ In other cases, it is known that the altar in question had a confessio underneath that may have furnished space for bigger relics than particles in a small sepulchrum. This is true for S. Lorenzo in Lucina, where "bodies" of various saints are deposited "in the high altar" along with smaller objects and minor particles, without any specification of the exact location (HB 19 / 29). The new altar in S. Sebastian's crypt under the ancient basilica at the Via Appia was built above Sebastian's tomb (1218). The inscription suggests that the "corpus sancti Sebastiani" was rearranged in the altar itself, where it was joined with relics of apostles and other Early Christian saints (HB 31). It cannot however be said definitively that a real elevation of the saint's body took place in order to concentrate all the relevant relics in the altar block itself.

A further few cases stand out in that the usual format of the inscription is extended with narrative digressions that refer to a more complicated disposition of relics. This is true for the diaconia of S. Eustachio, where relics are mentioned "in maiori altari", apart from "bodies" of saints "sub altari maiori in conca onichina" (HB 28). ${ }^{61}$ The wording suggests that all the relics were already in situ in the preceding church. In the high altar, a usual series of relics was located, obviously small fragments, referred to as "of" or "from", like "of the wood of the Lord's cross / of the garments of Peter and Paul, of the coals of St. Lawrence".

However, in the space underneath the altar, relics of another category are indicated: the bodies of saints directly related to the cult of the church, videlicet Eustace and his wife and two sons, gathered in an onyx sarcophagus, obviously located in a confessio below floor level, grandly entitled 'mausoleum'. The shrine of onyx had a marble inscription with the names of the Eustace's martyr family. Unique in a consecrative inscription, the consecrator gets up to speak in first person: "I, Celestine... together with the previously mentioned bishops, saw the bodies of the saints with my own eyes and touched them with my own hands and deposited them anew, together with the old inscription, in the mausoleum beneath the altar".$^{62}$ The pope wants to emphasize the importance of the event, but he is referring to a disposition that is not unusual in Roman churches: under the altar and the presbytery is a chamber or a crypt containing one or more sarcophagi with the remnants of prominent saints, transported to these urban churches sometime in the Early Middle Ages. ${ }^{63}$ The term mausoleum is less usual than confessio, but has a strong rhetorical impact on this almost dramatic turn of phrase in an initially seemingly predictable inscription text.

The inscription from S. Adriano, known only from Early Modern transcriptions, is quite atypical (HB 32) ${ }^{64}$ It starts with the story of the 'discovery' of the holy bodies of Marius and Martha and relics of St. Hadrian "in confessione sub maiori altari" in 1228. Also, relics of "the three boys" were found "in absidae supra columnam primam". Obviously as a result of this discovery, the cardinal deacon Stephen de Normandis organized a rearrangement of the relic treasure of the diaconia and concomitantly a re-dedication of the church by pope Gregory IX. In the epigraph, mounted in the apse, a long series of relics was listed, none of them said to have been transported from elsewhere or even deposited anew during the

\footnotetext{
${ }^{60}$ HOLST BLENNOW, Inscriptions p. 267.

${ }^{61}$ ANNOSCIA, Scritture.

62 Translation HolST BLENNOW, Inscriptions p. 132; cf C. BOLGIA, Celestine III's relic policy and artistic patronage in Rome, in: Pope Celestine III, 1191-1198: diplomat and pastor. J. DORAN / D. J. SMITH eds. (2007), p. 237-270, esp. p. 261-263.

${ }^{63}$ For the confessio (without a crypt) in S. Eustachio see CLAUSSEN, Kirchen 1, p. 461-463.

${ }^{64}$ A. HOLST BLENNOW, A puzzle from medieval Rome: reconstruction of an inscription from the medieval church of S. Adriano in the Roman Forum, in: Opuscula Romana 31/32 (2006/ 2007) [2008], p. 203-208.
} 
consecration. The entire operation seems an enormous exploit of propaganda for the relic collection of the historical church on the Forum Romanum (fig. 05). Many relics are said to be located inside the high altar, among them several "bodies" including St. Hadrian. The altar stood in front of the apse above a platform that contained an annular crypt. ${ }^{65}$ This crypt is referred to as confessio, which from the High Middle Ages onward is not unusual in Rome. ${ }^{66}$ What is more striking, is that, in contrast to S. Eustachio, the substantial relics were in the high altar instead of in the subterranean chambers. This was probably changed by cardinal Stephen, because after the consecration "the larger part of the bodies of the saints mentioned ... is in the confessio": among them Hadrian and other corpora that had previously been in the altar. Later recognitions confirm the existence of several marble reliquaries in the crypt. ${ }^{67}$ The inscription also offers information about the further disposition of relics in the church. In the absidae above the first column where the three holy boys had been discovered, a large number of relics was now installed. It is improbable that the term can simply be translated with "apse", which makes no sense in a church with one central apse and a colonnade with arches. "The first column" of the colonnade was directly besides the high altar, and the absidae were obviously cupboards for relics mounted on or placed in the upper side wall. ${ }^{68}$ Relic containers or tabernacles in walls were not unknown in Rome. ${ }^{69}$ Finally, the inscription specifies that certain relics were kept in mobile containers, namely the heads of Marius and Martha, separated from their bodies, in a silver casula. It was certainly usual in many churches to reserve special relics for mobile use or public exposure and to keep them in the sacristy.

The material aspects of the relics as well as their hierarchy of significance and cult status are topics that deserve further investigation and for which the consecrative inscriptions are an inexhaustible source. I recall that the deposition of relics was the most ancient core of the rite of church consecration in Rome. Against this background, the central message of our consecrative inscriptions is clear: for every Roman church, particularly when newly consecrated, it was necessary to have at least an associative link with the Early Christian martyria, which had been the real treasure of the Christian city for many centuries.

Sible de Blaauw Radboud University Nijmegen, Institute for Historical, Literary and Cultural Studies

\footnotetext{
${ }^{65}$ Claussen, Kirchen 1 p. 34-36.

${ }^{66}$ DE BlaAuW, Cultus et decor p. 745 seq..

${ }^{67}$ Holst BlENNOW, Inscriptions p. 151 seq.; A. MANCINI, La chiesa medioevale di S. Adriano nel Foro Romano in: Atti della Pontificia Accademia Romana di Archeologia - Rendiconti 40 (1967-1968), p. 191-245, esp. p. $238-241$.

${ }^{68}$ Absis can denote a reliquary in medieval texts, but I know not any example in Rome. I do not exclude a transcription error.

${ }^{69}$ The most famous example in the triumphal arch of S. Croce, CLAUSSEN, Kirchen 1 p. 431 seq.
} 